\title{
Pest management through tropical tree conservation
}

\author{
Martín Aluja • John Sivinski • Roy Van Driesche • Alberto Anzures-Dadda • \\ Larissa Guillén
}

Received: 16 November 2013/Revised: 14 January 2014/Accepted: 21 January 2014/ Published online: 1 February 2014

(C) The Author(s) 2014. This article is published with open access at Springerlink.com

\begin{abstract}
Tropical trees can provide various ecological services to adjacent agricultural environments, including maintaining and amplifying the numbers of beneficial insects. In Mexico, certain tree species harbor a diverse guild of hymenopteran parasitoids that attack pest fruit flies (Diptera: Tephritidae) and are at the same time sources of valuable hardwood timber. Indigenous trees and their associated fauna are slowly disappearing due to forest clearance and the expansion of crop monocultures. Here we explore the relationship among pest and non-pest fruit flies, their fruit-hosts and parasitoids in the context of mango orchards and surrounding patches of uncultivated vegetation and propose a novel mechanism to use these associations in favor of conservation purposes and pest management. Trees of conservation biological control interest are classified as: (1) parasitoid multiplier plants, species that serve as alternate hosts for key fruit fly pests when their commercial hosts are not available, but in which they are unusually vulnerable to parasitism; (2) parasitoid reservoir plants, native or introduced trees in whose fruits non-pest fruit flies serve as hosts to generalist parasitoids that are able to attack pest tephritids in other species of commercially grown fruit; and (3) pest-based parasitoid reservoir plants, native or
\end{abstract}

Alberto Anzures-Dadda-Deceased

Communicated by Vun Khen Chey.

M. Aluja $(\varangle) \cdot$ A. Anzures-Dadda · L. Guillén Instituto de Ecología, A.C., Apartado Postal 63, 91000 Xalapa, Veracruz, Mexico e-mail: martin.aluja@inecol.mx

J. Sivinski

Center for Medical, Agricultural \& Veterinary Entomology, 1600/1700 SW 23rd, Gainesville, FL 32608, USA

R. Van Driesche

PSIS, Division of Entomology, University of Massachusetts, Amherst, MA 01003, USA

A. Anzures-Dadda

El Colegio de la Frontera Sur, Área Conservación de la Biodiversidad, San Cristóbal de Las Casas, Chiapas, Mexico 
introduced species that are not economically important locally, but which harbor fruit flies that would be pests in other circumstances and that serve as hosts for parasitoids of the important pests in the vicinity. Protection, multiplication and dissemination of such tree species has the potential to increase the number of naturally produced fruit fly parasitoids and could assist in the management of tephritid pests in areas where destruction of forests has impoverished the historical sources of fruit fly natural enemies. Tropical forest conservation may help resource-poor farmers reduce crop losses, increase biodiversity within fruit-growing regions and conserve native forests for both conservation purposes and commercial use of native hardwoods.

Keywords Tephritids · Parasitoid conservation · Forest conservation · Conservation biological pest control $\cdot$ Agroecology

\section{Introduction}

Preservation of natural habitats in Latin America, Africa and Asia is often a daunting task given rapid population growth and agricultural expansion with concomitant high levels of deforestation (Harvey et al. 2008; Bradshaw et al. 2009). However, these lost habitats could have provided ecological services to agricultural environments and if the value of tropical forests to natural pest control were more widely recognized, small-rural landowners of forest might be more likely to protect, even restore, adjacent woodlands. At a governmental level, informed politicians would be in a stronger position to legislate and enforce conservation measures (Newton et al. 2009).

As an illustrative example, we consider the relationship among tephritid fruit flies, several of which are important pests in southern Mexico, their parasitoids, and the trees on which both ultimately depend. Specifically, we consider in detail an area of 900 ha (Fig. 1) located in the center of Veracruz State in the vicinity of Apazapan $\left(19^{\circ} 198 \mathrm{~N}, 96^{\circ} 428 \mathrm{~W}\right.$; 347 masl), Llano Grande (19²28 N, 96538 W; 950 masl), Tejería, (19²28 N, $\left.96^{\circ} 568 \mathrm{~W} ; 1,000 \mathrm{masl}\right)$ and Monte Blanco (19²38 N, $96^{\circ} 568 \mathrm{~W} ; 1,050$ masl). This area of mixed agriculture and uncultivated vegetation contains about $12 \%$ of the plant diversity in Mexico and of this diversity $30 \%$ is endemic (Rzedowski 1996). We argue that a number of the local, largely native, fruit tree species act as critical reservoirs that conserve key parasitoids of tephritid pests (Hernández-Ortiz et al. 1994; Lopez et al. 1999; Sivinski et al. 2000; Aluja et al. 2003, 2008) and that other fruit trees not only conserve these parasitoids but greatly amplify their numbers. We explain that deforestation resulting in forest fragmentation, as well as selective logging, threatens the trees and therefore the fruit fly parasitoids and the agricultural benefits they could provide. Conservation, multiplication and dissemination of such trees as components of non-orchard landscapes could result in increased fruit yields and produce a supply of valuable timber and wood products for rural landowners (Harvey et al. 2008).

\section{Interactions among Tephritidae, hymenopteran parasitoids and fruit trees}

Some fruit flies are among the world's most damaging agricultural insect pests (Aluja and Mangan 2008). The economically important genera are Anastrepha, Bactrocera, Ceratitis, 


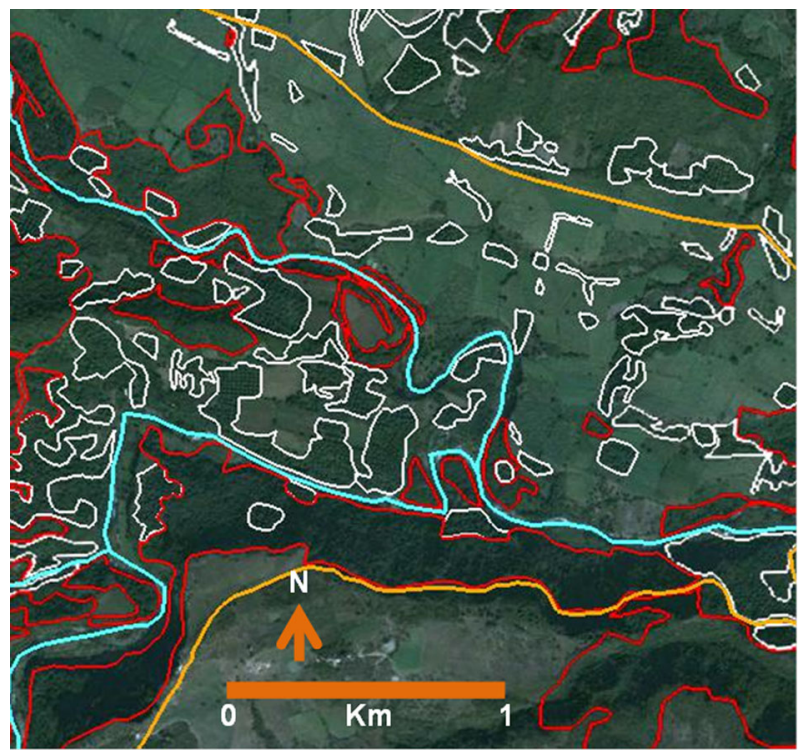

Fig. 1 Aerial photo of Las Juntas on the Rio Pescados near Llano Grande, Veracruz $\left(12^{\circ} 22^{\prime} 18.64^{\prime \prime} \mathrm{N}, 96^{\circ}\right.$ $51^{\prime} 18.98^{\prime \prime} \mathrm{W}$ ), showing fragmentation of native forest in different successional status (red polygons) and the placement of these fragments with respect to orchards (white polygons), pastures, sugar cane and other crops (light green areas, not marked with polygons). Primary and secondary forest fragments are primarily located in rough or inaccessible areas such as canyons (blue lines). The landscape is crossed by a main road (yellow line). Source Google Earth

Rhagoletis, and Toxotrypana, all of which are represented in the subtropical and tropical regions of the Americas. Anastrepha species, the focus of our discussion, are distributed from the southern United States to northern Argentina (Hernández-Ortíz and Aluja 1993; Aluja 1994). In Latin America, many species of native plants in tropical dry and wet forests support fruit fly larvae of both economic $(<5 \% ; 7$ species $)$ and non-economic importance (>95\%; >200 species) (Aluja et al. 2003 and references therein). In developed areas these same plants can also be found as isolated individuals that have either survived agricultural practices or been planted as living fences or fruit or shade trees. Semi-commercial and commercial orchards in Mexico are often located near or even mixed into patches of native vegetation that include tephritid hosts, particularly if the adjacent sites, such as canyon walls, do not lend themselves readily to cultivation (Fig. 1).

Movement between wild and cultivated hosts (described in detail by Aluja and Birke 1993; Aluja and Rull 2009) is typical of several important pest fruit fly species and is important to their population survival because: (1) no single host species fruits throughout the year; and (2) pest fruit flies do not diapause and adults survive for only limited periods; thus they have no mechanism to bridge fruit-free periods (Aluja et al. 1998, 2009).

\section{Anastrepha spp. control}

Toxic bait sprays have been used extensively to control pest Anastrepha species (Aluja 1994; Raga and Sato 2005). But the sterile insect technique (SIT) (Reyes et al. 2000), classical biological control (Eskafi 1990; Ovruski et al. 2000) and augmentative releases of parasitoids (Sivinski et al. 1996; Montoya et al. 2000, 2007) have resulted in complete or 
partial control of pest tephrtid populations at certain times and places. Recently, a series of biorational techniques such as trap crops, modified orchard design and the use of behaviormodifying chemicals have been proposed (see Aluja and Rull 2009 and references therein). In spite of these alternatives, a large share of small-scale fruit growers in the Neotropics still rely on calendar-based applications of broad-spectrum insecticides such as malathion sprayed singly or in combination with hydrolyzed protein used as a bait (Aluja 1994; Moreno and Mangan 2002; Mangan and Moreno 2007) or more recently, the bacteriaderived insecticide spinosad (McQuate et al. 2005). Despite their effectiveness, resistance (Wang et al. 2005; Hsu and Feng 2006), negative impact on natural enemies or on other non-target organisms (Stark et al. 2004), as well as water and soil pollution (Favari et al. 2002; Murray et al. 2010), and deleterious effects on human health (Band et al. 2011; Hernández et al. 2013; Kjeldsen et al. 2013), call for more environmentally-friendly alternatives such as the one proposed here.

Classical biological control projects targeting Anastrepha species resulted in the establishment of exotic larval-pupal and pupal fruit fly parasitoids in Mexico (Aluja et al. 2008). However, many native parasitoids, particularly wasps of the family Braconidae that attack tephritid larvae and prepupae, play a role in control of pest fruit flies (Lopez et al. 1999; Ovruski et al. 2000). Indigenous species are particularly abundant in forest-fruits and non-commercial landscape fruit trees (Sivinski et al. 2000). Naturally occurring suppression in these adjacent areas could reduce the number of adult fruit flies available to move into orchards. Enhancing biological control on pest reservoirs to prevent agricultural infestations follows the same rationale behind a number of augmentative projects that mass-release natural enemies into neighboring rather than cultivated areas (Sivinski et al. 1996; Montoya et al. 2000).

Fruit trees that benefit biological control and conservation

Trees of conservation biological control interest are classified here as: (1) parasitoid multiplier plants, species that serve as alternate hosts for key fruit fly pests when their commercial hosts are not available, but in which they are unusually vulnerable to parasitism; (2) parasitoid reservoir plants, native or introduced trees in whose fruits non-pest fruit flies serve as hosts to generalist parasitoids that are able to attack pest tephritids in other species of fruit; and (3) pest-based parasitoid reservoir plants, native or introduced species that are not economically important locally, but which harbor fruit flies that would be pests in other circumstances and that serve as hosts for parasitoids of the important pests in the vicinity. As the name suggests, this last category is a special case of reservoir plants (Fig. 2).

\section{Parasitoid multiplier plants}

Preemptive biological control measures applied to indigenous-host reservoirs are aimed at suppressing pest tephritid populations when they are most vulnerable (Sivinski and Aluja 2012). Mexican opiine braconids must drill with their ovipositors through fruit pulp to reach their larval hosts. Ovipositors can simply be too short to reach deeply feeding larvae and the time required to attack those deep-hosts and dangerous exposure to predators may be prohibitive. As a result, the shallower the fruit pulp, both within and among fruit species, the higher the prevalence of parasitism (Sivinski 1991; Sivinski et al. 2001). Noncommercial fruits are generally smaller than commercial species which are often bred for large size (Tanksley 2004). Thus parasitism in native fruits such as Spondias mombin. and 


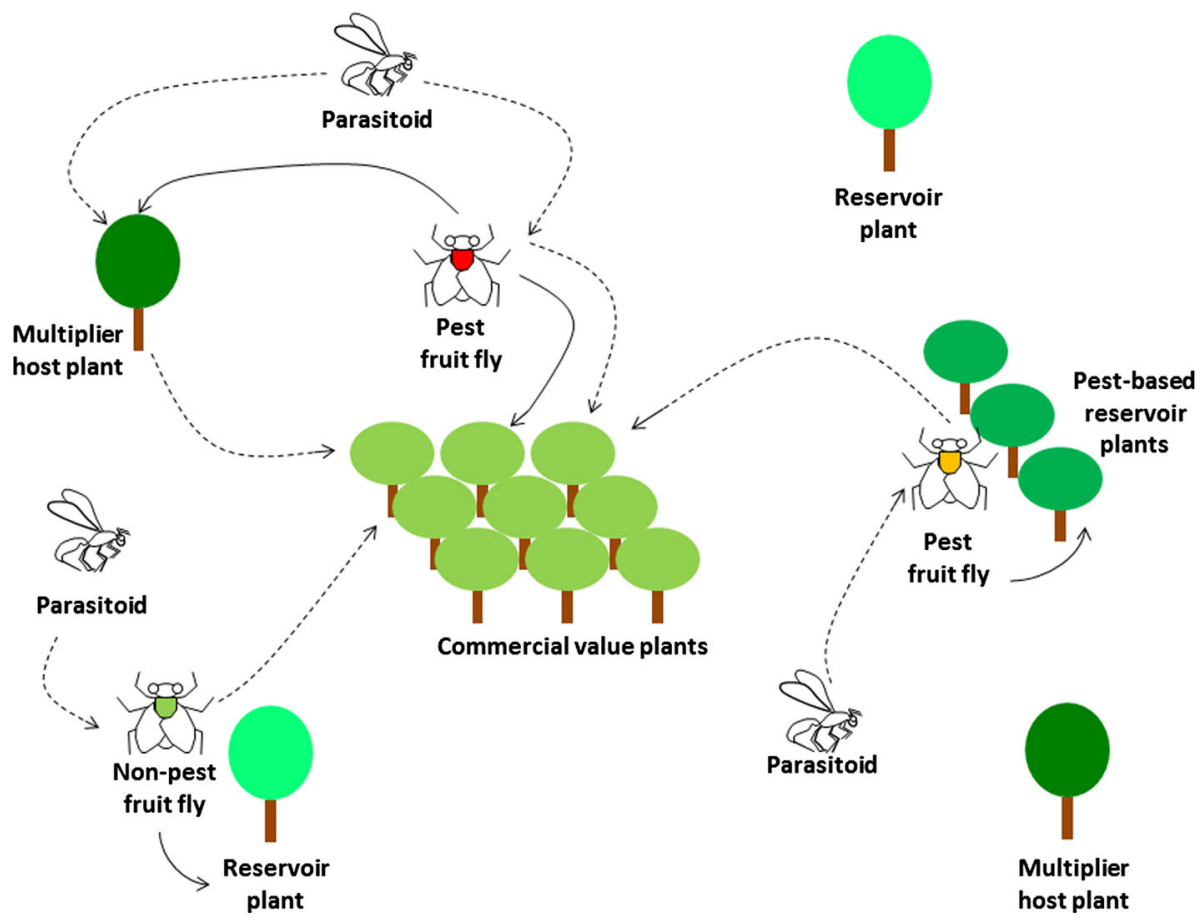

Fig. 2 Scheme of reproduction dynamics patterns for pest and non-pest fruit flies and their parasitoids among cultivated (with commercial value or not) and wild trees in an area with anthropogenic landscape (commercial orchards) next to natural forest as an example of pest management through tropical tree conservation.(continuous line) Fruit fly trajectory; (dashed continuous line) parasitoid trajectory

Tapirira mexicana Marchand, can be higher than $90 \%$, but less than $1 \%$ in the much larger and exotic mango (Mangifera indica) (Fig. 3), (Table 1).

Certain small-fruited indigenous plants serve as alternate hosts for key fruit fly pests. Since levels of parasitism in the fruit of these native species can be very high, they multiply the local parasitoid population (Tables 2, 3). An individual "parasitoid multiplier plant" can produce over 20,000 parasitoids per tree. In the case of the West Indian fruit fly (Anastrepha obliqua [Macquart]), which attacks mango, the indigenous S. mombin, Myrciaria floribunda (H. West ex Willd.) O. Berg, and T. mexicana are important alternate host plants. On these alternate hosts, parasitoids derived from fruit fly/tree combinations directly affect the "off season" A. obliqua population when the crop itself is not in fruit. The high parasitism that occurs on these plants has the potential to drive A. obliqua population survival rates to near or below replacement levels and reduce the number of flies re-entering mango orchards in the next crop cycle, although this concept has not been the subject of systematic study.

\section{Parasitoid reservoir plants}

Because Anastrepha species in Mexico share a pool of genus-level generalist parasitoids, some of the wasps that attack pest fruit flies on their indigenous host plants develop in a large variety of fly species (Lopez et al. 1999; Sivinski et al. 2000, 2001). These tephritids 
Fig. 3 Commercial fruit (mangoes in top row) are 10-25 times larger than fruits of wild plants such as Tapirira Mexicana (next to coin) and Spondias spp. (all others in bottom row), two species in Veracruz, Mexico that are off season hosts of pest fruit flies. Large fruit size provides a partial refuge to maggots from parasitism

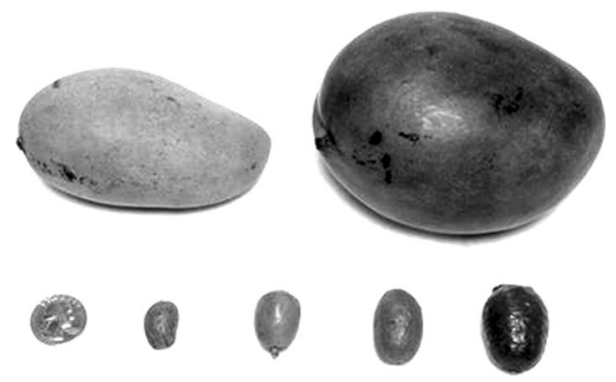

are mostly native species of no economic importance that breed in fruits of a variety of uncultivated trees. The fruit of such trees serve as sources of parasitoids that can move and attack the target pest on its non-commercial and commercial hosts. We term such trees "parasitoid reservoir plants", some of which serve as hosts for several non-pest fly species that are parasitized by 1-3 species of generalist parasitoids (see Tables 2, 3). For example, the native non-pest fruit fly Anastrepha alveata Stone develops in the fruit of the native reservoir plant Ximenia americana (Olacaceae). This fly is a host for three generalist native braconids, Doryctobracon areolatus (Szépligeti), Utetes anastrephae (Viereck), and Opius hirtus Fischer (Lopez et al. 1999), the first two of which are the dominant species in the natural enemy guild attacking the pestiferous A. obliqua.

\section{Pest-based parasitoid reservoir plants}

Useful parasitoids are sometimes produced in fruit flies that are pests in other regions but not locally. For example, in the mango production region of Veracruz, Mexico, neither $A$. ludens (a key pest of citrus) nor Anastrepha striata Schiner (a pest of guava [Psidium guajava]) are of concern because neither citrus nor guava are grown commercially in the region. Both species of tephritids are attacked by parasitoids that also attack A. obliqua, the major fruit fly pest of mangoes. Therefore under these particular circumstances citrus and guava serve as natural enemy reservoir plants, termed here "pest-based parasitoid reservoir plants". In small-fruited pest-based parasitoid reservoir plants (e.g., P. guajava, Psidium guineense Sw.) tephritids are parasitized at moderate to high rates (30-75\%) by five native and two exotic species of generalist parasitoids (Tables 2, 3; Lopez et al. 1999; Sivinski et al. 2000). In citrus-producing regions, A. obliqua and A. ludens switch biological control roles, with tropical plums (Spondias spp.) infested with A. obliqua becoming a pest-based reservoir for parasitoids of $A$. ludens in smaller diameter citrus or non-commercial fruit which helps reduce populations present in larger commercially grown citrus.

Vulnerabilities of fruit trees useful to biological control and conservation

Habitat loss is a major threat to species persistence (Fischer and Lindenmayer 2007; Mortelliti et al. 2010). In terms of trees useful to biological control and conservation, the effects of habitat loss can be examined at the levels of both the landscape and of the individual tree. At the landscape-scale, deforestation and forest fragmentation pose major threats while on the scale of individual trees, selective logging endangers parasitoid reservoirs. 
Table 1 Rank order of fruit trees based on yield of parasitoids (number of parasitoids/kg of fruit) and on species richness of parasitoids harbored

\begin{tabular}{lcll}
\hline Tree species & $\begin{array}{c}\text { Weight }(\mathrm{g}) / \mathrm{fruit} \\
(\mathrm{mean} \pm \mathrm{SE})\end{array}$ & $\begin{array}{l}\text { Rank total parasitoids } \\
\text { \# parasitoids/kg fruit) }\end{array}$ & $\begin{array}{l}\text { Rank no. parasitoid } \\
\text { species }\end{array}$ \\
\hline Spondias mombin & $5.13(0.03)$ & $1(206.7)$ & $7(3)$ \\
Tapirira mexicana & $3.06(0.04)$ & $2(35.8)$ & $3(4)$ \\
Ximenia americana & $4.89(0.05)$ & $3(33.8)$ & $4(3)$ \\
Psidium guajava & $25.97(0.36)$ & $4(22.9)$ & $1(7)$ \\
Spondias radlkoferi & - & $5(15.5)$ & $4(3)$ \\
Spondias purpurea & $18.09(0.12)$ & $6(10.7)$ & $5(2)$ \\
Citrus sinensis cultivar "Corriente" & $145.58(2.24)$ & $7(8.7)$ & $2(5)$ \\
Psidium sartorianum & $1.81(0.02)$ & $8(8.1)$ & $3(4)$ \\
Psidium guineense & $3.82(0.21)$ & $9(6.7)$ & $1(7)$ \\
Mangifera indica cultivar "Kent" & $816.82(32.31)$ & $10(0.8)$ & $5(2)$ \\
\hline Data coll &
\end{tabular}

Data collected in central Veracruz, Mexico (from Lopez et al. 1999; Sivinski et al. 2000)

\section{Habitat fragmentation}

Mexico had nearly 63 million hectares (ha) of forest in 2000, of which about half were tropical forests. However, at the present rate of conversion to farming and ranching this could rapidly disappear. Between 1993 and 2000 approximately 3.1 million ha of forests were cleared for farmland and 5.1 million ha for pasture (Velázquez et al. 2002). The original vegetation of the mango production area in Veracruz was tropical deciduous forest, but currently there are remnants of original vegetation containing patches of different successional stages, surrounded by mango orchards and smaller areas of sugarcane crops, pastures and roads (González-Astorga and Castillo-Campos 2004; Castillo-Campos et al. 2008). At this time, there is no detailed information about the loss of particular species of trees, particularly those that host tephritids and their parasitoids, in Veracruz or other regions of Mexico.

In fragmented landscapes, species numbers tend to decrease with increasing distance from a source habitat such as an extensive forest (Kruess and Tscharntke 2000). However, the effects of habitat fragmentation on a particular species will depend on specific behaviors (Kareiva 1987), especially on the ability to move among patches (Corbett and Plant 1993). While fragmentation affects species from all trophic levels to some degree, upper trophic level organisms, specifically hymenopteran parasitoids, are often more severely affected than the species they attack (e.g., Klein et al. 2006; Antón et al. 2007; Bergerot et al. 2010). In part this is because many parasitoids, including those of pest tephritids, have movement-ranges that are substantially shorter than those of their hosts (Messing et al. 1994, 1995, 1997; Nouhuys and Hanski 2002; Thies et al. 2005; Bergerot et al. 2010). In a Caatinga-Cerrado ecotone in Brazil, the number of tephritid parasitoid species in a patch was higher in areas with adjacent forest fragments (De Souza et al. 2012).

Another difficulty restricting the reproductive success of parasitoids relative to their hosts in a fragmented landscape, is that parasitoids must find a plant patch that is occupied by the susceptible fly species, while any patch of suitable host plants can be colonized by a tephritid (Nouhuys and Hanski 2002). 


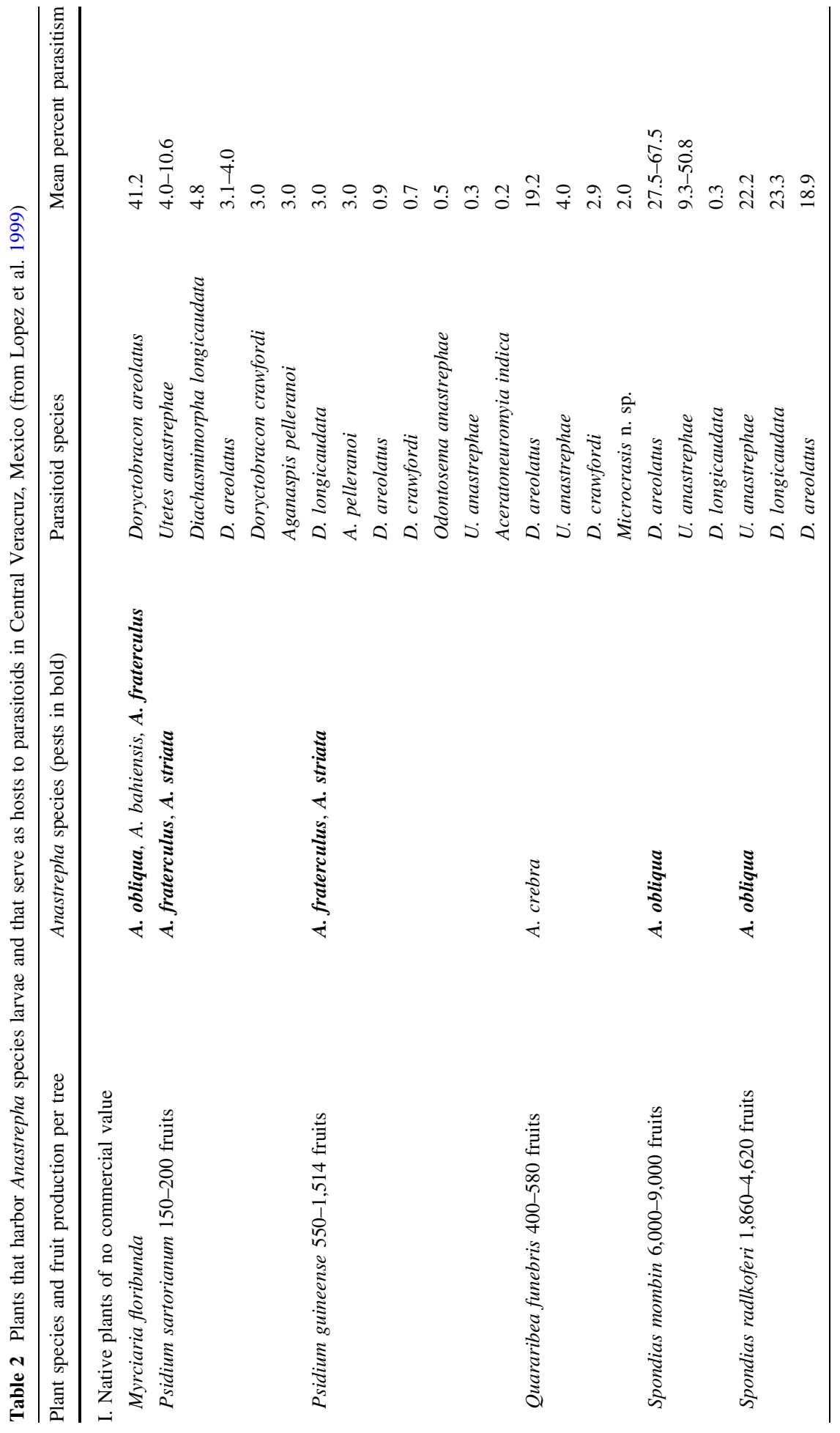




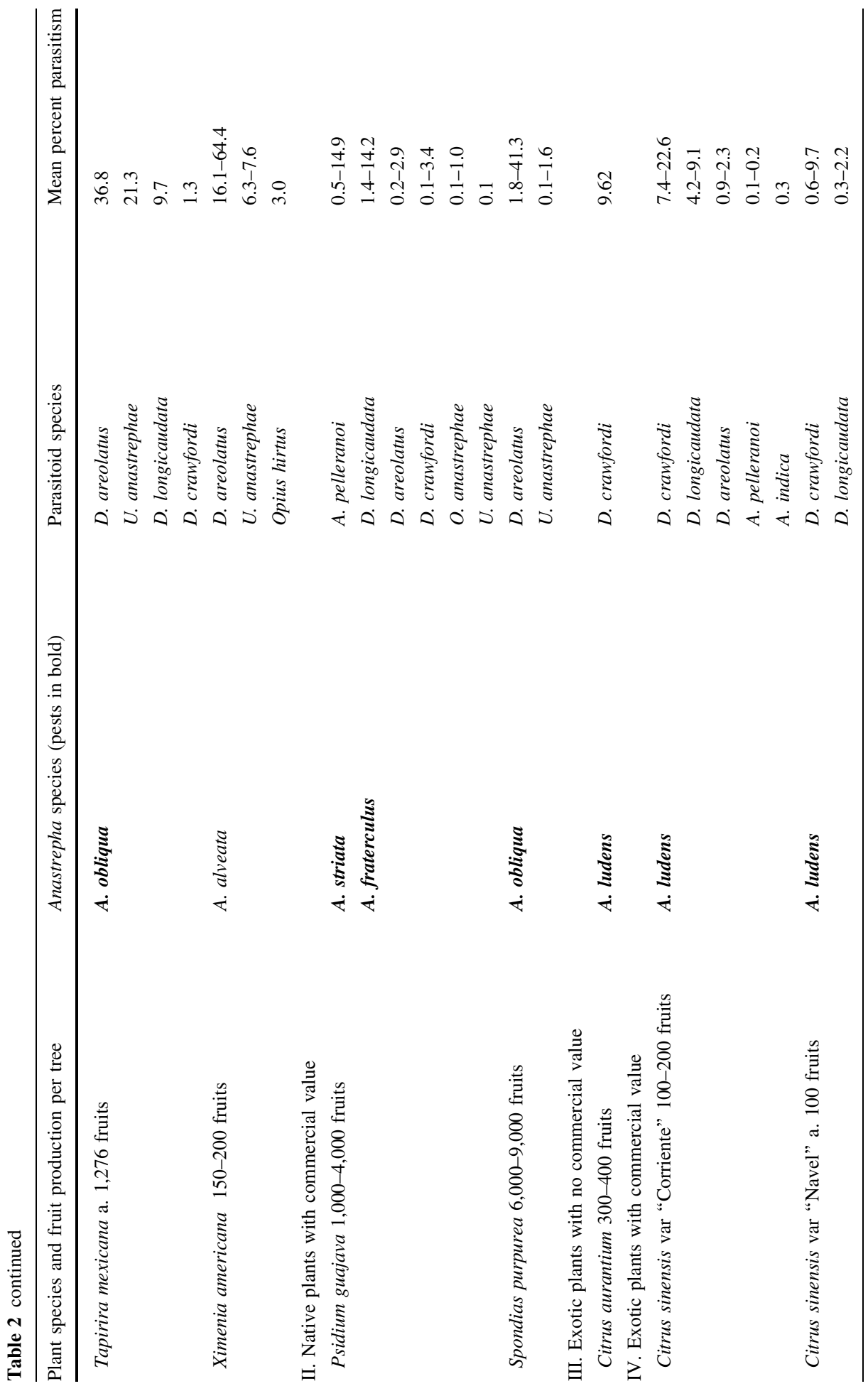




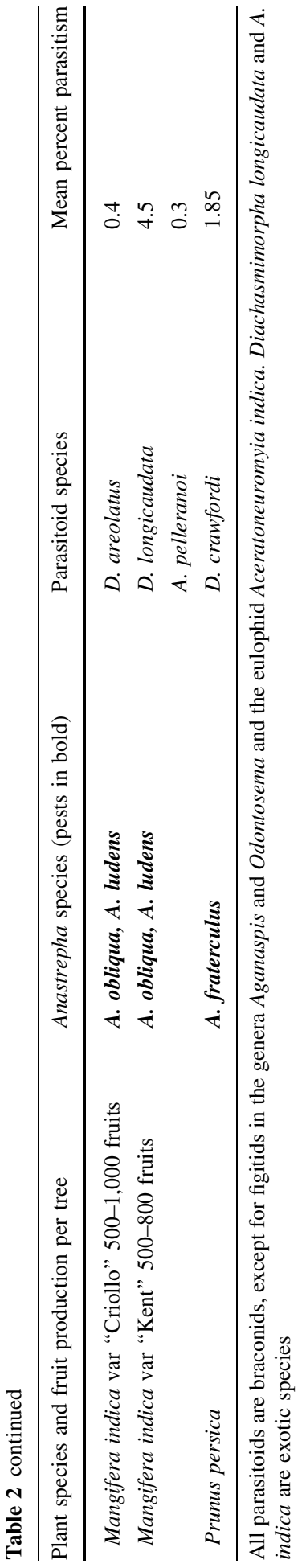

Springer 


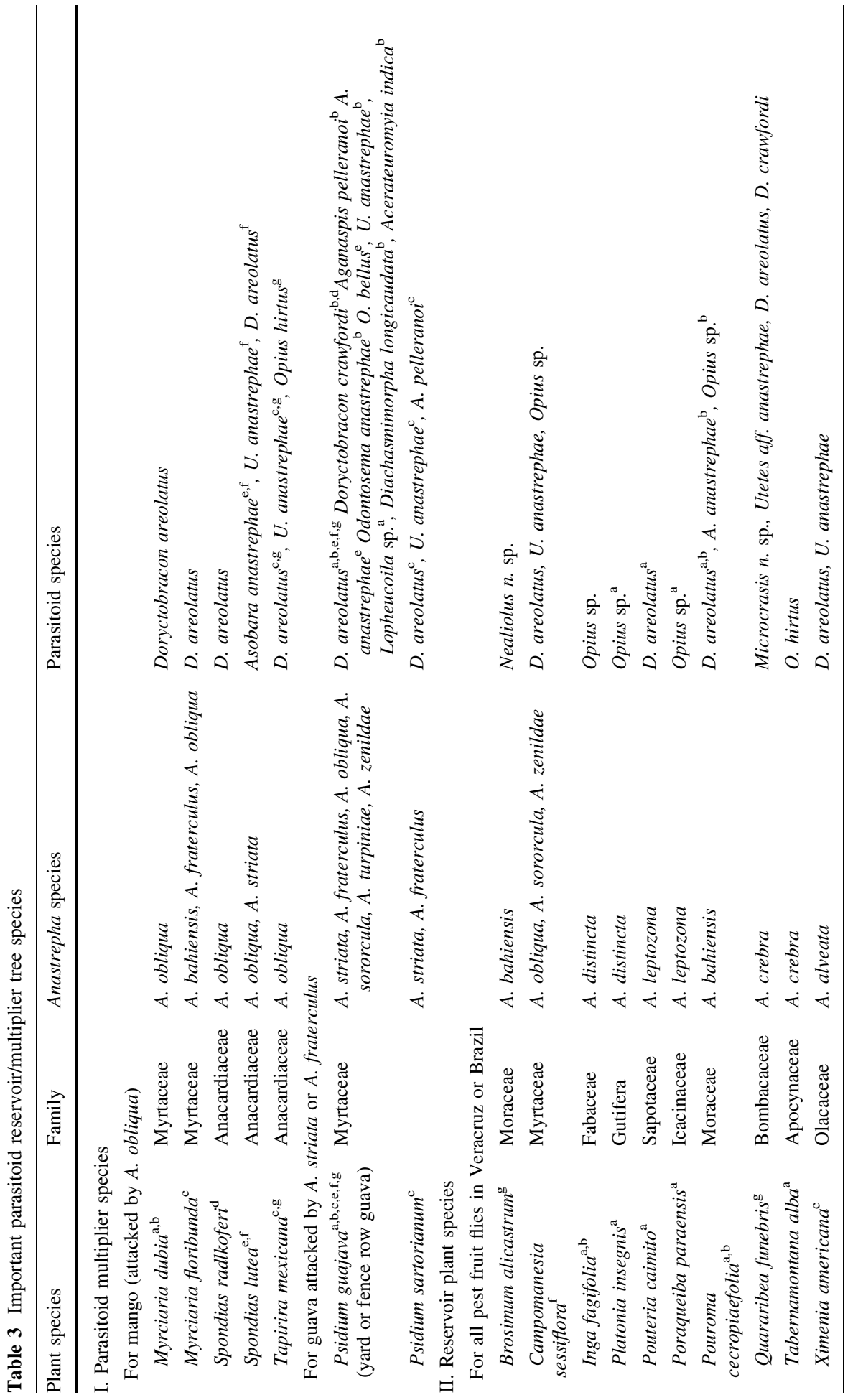




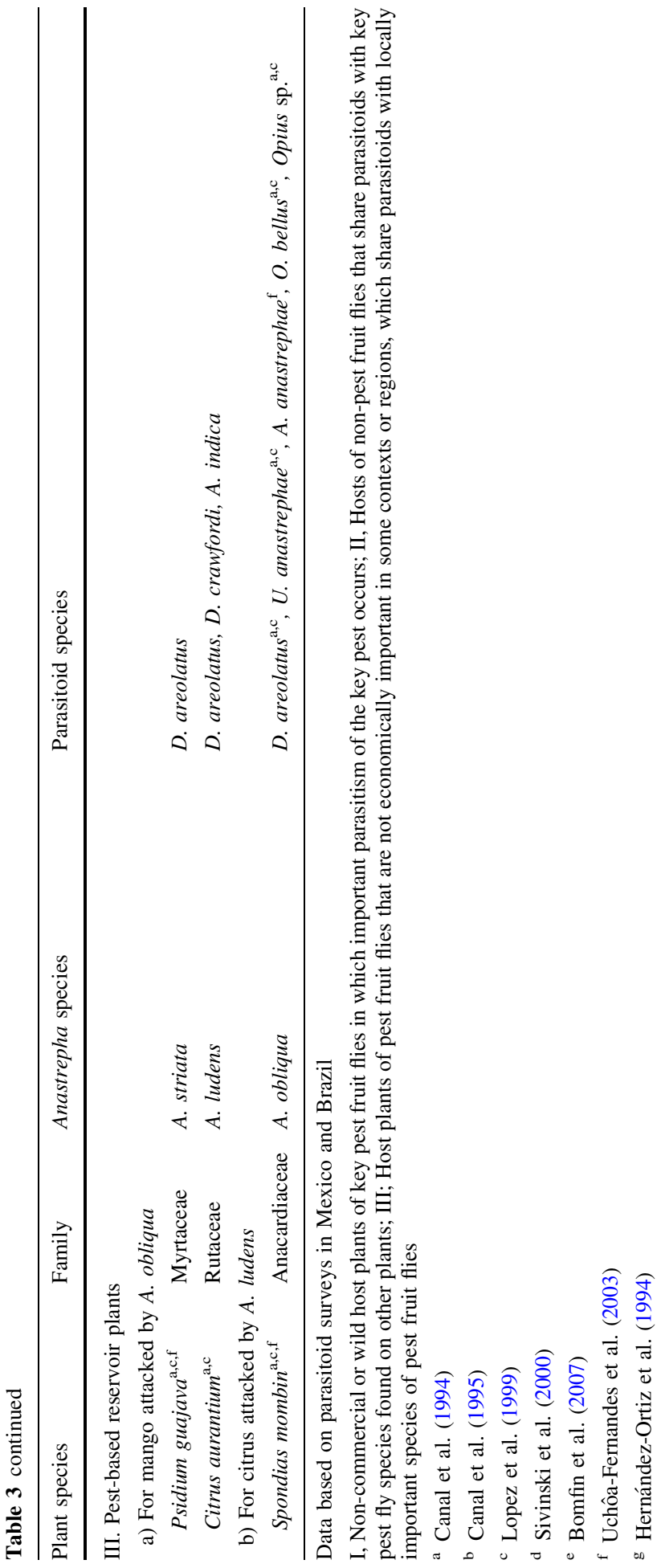


These two variables, distance between patches and heterogeneous patch quality, can combine to decrease parasitism with increasing fragmentation so that in general parasitism rates tend to be lower in small patches than in large ones (Kruess and Tscharntke 2000). For example, in France, parasitism of larvae of the butterfly Pieris brassicae by the braconid wasp Cotesia glomerata, declined more rapidly along a fragmentation gradient from the countryside into the center of a large urban area (Paris) than did abundance of the butterfly itself (Bergerot et al. 2010).

The negative effects of habitat fragmentation on population size may be mitigated by high resource density (Thompson 1996). However, in the mango region of Veracruz, resource density is higher for fruit flies, which are able to breed in orchard fruits, while their parasitoids have difficulty exploiting fly larvae feeding in large commercially grown fruit (Sivinski and Aluja 2012).

Circumstantial evidence suggests that the above-cited principles apply to both fruit flies and their parasitoids when native forests in this region become increasingly fragmented. Reductions in fruit fly parasitoid species richness appear to be associated with habitat loss (Table 4). In the Apazapan site, where most of the native forest survives in small isolated patches and wild fruit fly hosts for parasitoids are rare, only the two most widespread parasitoid species occur whereas a six-species complex is found in a similar area, the Llano Grande site, where many fruit fly hosts are still present in larger contiguous areas. Parasitoid abundance is $96 \%$ lower in the highly perturbed site (Lopez et al. 1999).

\section{Selective logging}

In addition to widespread forest fragmentation, the selective cutting of indigenous trees used by various Anastrepha species, and ultimately their parasitoids, degrades the potential of forests to provide ecological services to agriculture. For example, T. mexicana (false mahogany) is both an important parasitoid multiplier plant and a highly valuable timber tree and source of veneer wood. It is subject to heavy exploitation without replanting. In the past, government programs in Mexico mandated the removal of wild fruit fly host plants on the unproven assumption that such removals would lower pest fly densities. Such practices contradict current governmental efforts to protect biodiversity (CONABIO 2008). For example, Spondias radlkoferi Donn. Sm., a native host plant of A. obliqua that can produce hundreds even thousands of parasitoids annually, cannot be legally cut or removed in Mexico (NOM 059-ECOL-2001). However, farmers do not necessarily follow this change in policy and local knowledge of the potential pest management value of such trees is limited or completely lacking.

\section{Managing links between wild fruit fly hosts and orchards to promote biological control and conservation}

The selective addition, and/or maintenance of fruit fly host plants in orchard agroecosystems in southeastern Mexico may lead to the conservation and amplification of native fruit fly parasitoids and ultimately generate increased yields and decreased insecticide use. To summarize the argument to this point, many fruit fly parasitoids are generalists that typically move seasonally among various fruit fly species found on a variety of crop and non-crop fruits spread spatially over a significant area (Lopez et al. 1999; Aluja et al. 1998). Loss of key tree species in uncultivated patches and the corridors connecting these patches in areas surrounding orchards would negatively affect parasitoid populations. 
Table 4 The abundance of tephritid parasitoids sampled during 4 years in 15 wild and cultivated plant species in Central Veracruz, Mexico (modified from Lopez et al. 1999)

\begin{tabular}{llcc}
\hline Study site & Parasitoid species & $\begin{array}{c}\text { N (individuals } \\
\text { per 1,000 fruit) }\end{array}$ & $\begin{array}{c}\text { Parasitoid dominance at each } \\
\text { site (percentage of all } \\
\text { parasitoids recovered) }\end{array}$ \\
\hline $\begin{array}{l}\text { Llano grande } \\
\text { (undisturbed area) }\end{array}$ & $\begin{array}{l}\text { Doryctobracon areolatus } \\
\text { Utetes anastrephae }\end{array}$ & 5,864 & 52.60 \\
& Diachasmimorpha longicaudata & 7,140 & 46.11 \\
& Opius hirtus & 36 & 0.70 \\
& Aganaspis pelleranoi & 22 & 0.32 \\
& Doryctobracon crawfordi & 7 & 0.20 \\
& Total & 11,147 & 0.03 \\
& Doryctobracon areolatus & 437 & 96.90 \\
Apazapan & Utetes anastrephae & 14 & 3.10 \\
Total & 451 & 100.00
\end{tabular}

All are opiine braconids, except for the figitid Aganaspis pelleranoi. Diachasmimorpha longicaudata is an exotic species

Practices that maintain or restore these native/uncultivated plants should increase rates of parasitism and decrease fruit fly survival in fruits of their wild hosts. This would limit the number of flies available to infest seasonally available commercial fruits. There are several types of these key fruit tree species. Since there are only a few previous examples of the manipulation of woody vegetation to enhance natural enemies and improve pest control (Boller et al. 1988; Smith and Papacek 1991; Corbett and Rosenheim 1996; Murphy et al. 1998; Tscharntke et al. 2007), and none of these focused on tephritid fruit flies, we have proposed the terms "parasitoid multiplier", "parasitoid reservoir" and "pest-based parasitoid reservoir" to described them.

An example: Anastrepha obliqua in mango production areas

As a way of illustration, we describe in detail the roles of non-commercial fruit trees and the insects they support in a particular crop/pest system, namely A. obliqua management in the mango-producing region of Veracruz, Mexico. Of the four major pest Anastrepha species in Veracruz, A. obliqua, the principal pest of mango, and A. ludens, the major pest of citrus, are the most suitable for suppression through conservation of wild host plants that enhance parasitism. Mango has a relatively short fruiting period (May-August), leaving eight other months in which A. obliqua must breed in the fruits of non-crop species (Fig. 4). A typical yearly population cycle in A. obliqua begins with invasion of mangoes in May, where it reproduces until the end of August. As mangoes become unavailable, the fly moves out of mango orchards in search of tropical plum fruits ( $S$. mombin) which begin appearing in July and continue through October. Also available in October are fruit of T. mexicana. The use of other fruit species during the period of November through January is unknown and it is possible that flies might survive this relatively cool period as immature stages developing slowly in fruits of the last known hosts, as pupae in the soil, or as long lived adults waiting in moist microhabitats. February through April, fruit of M. floribunda are available, although this plant is not common. Also in April/May there are fruit of 
Spondias purpurea, which completes the yearly cycle (Aluja et al. 2000). Various species of parasitoids attack A. obliqua in fruit of these different trees (Tables 2, 3). The most abundant parasitoids of $A$. obliqua are $D$. areolatus and $U$. anastrephae, and the former has been recovered from all four wild hosts in which A. obliqua breeds ( $M$. floribunda [Myrtaceae], S. mombin, S. purpurea, T. mexicana [all Anacardiaceae]), as well as the important pest-based parasitoid reservoir P. guajava (Myrtaceae) and the parasitoid reservoir $X$. americana (Olacaceae). Utetes anastrephae has similarly been recovered from A. obliqua in all of these tree species except $M$. floribunda. Levels of parasitism in these species are high, up to $92 \%$ (Lopez et al. 1999). In the case of S. mombin, one kilogram of fruit can yield up to 207 adult parasitoids (Table 1), which means that a single tree can produce over 20,000 parasitoids. Thus, in a patch of vegetation containing several $S$. mombin trees, several hundred thousand parasitoids can be produced at no cost.

We propose that area-wide reduction of A. obliqua pressure on mango orchards should be possible to achieve by reducing its breeding success in fruits of such wild species by promoting high levels of parasitism. If these native reservoir trees are locally rare, parasitoids may go locally extinct (Lopez et al. 1999) or attack hosts in lower numbers due to small parasitoid population sizes. When parasitism levels drop, A. obliqua survives in wild hosts at higher rates, producing more flies that subsequently return to infest commercial mango orchards. Below we discuss the specific actions that might promote higher levels of out-of-crop parasitism of $A$. obliqua immature stages.

Actions required for conservation biological control of A. obliqua

The best management of vegetation around mango orchards to suppress $A$. obliqua requires three types of actions: (1) conservation of existing forest patches; (2) development of nurseries of key species and replanting these in degraded forests, near orchards or in urban

\begin{tabular}{llllll}
\hline Fruit species & \multicolumn{5}{c}{ Period when species has fruit attackable by fruit flies } \\
\hline & Jan Feb Apr May Jun Jul Aug Sep Oct Nov Dec \\
Spondias purpurea & & & \\
Mangifera indica & & & \\
Spondias mombin \\
Spondias radkoferi \\
Myrciaria floribunda \\
Tapirira mexicana
\end{tabular}

Gray $=$ crops attacked

Fig. 4 Seasonal availability of fruits of trees used as hosts by Anastrepha obliqua in Veracruz, Mexico (modified from Aluja et al. 1998 and data in Table 2). Mango is the most economically important host, with Spondias purpurea (tropical plum) being only locally important. The remaining species represent wild hosts of no economic importance 
areas; and (3) legislation of an appropriate legal framework plus enforcement to foster agriculturally-productive biodiversity.

\section{Conservation of existing forest patches}

Protection of existing forest patches useful in conservation of fruit fly parasitoids should be made a conservation priority in Mexico. Implementation would begin with mapping of existing forest fragments and description of their relevant biodiversity, coupled with efforts to educate local farmers about the value of such fragments. Farmers in Veracruz are currently unaware that many of the native trees they cut down are useful to them as sources of beneficial insects and, at the same time, are sources of valuable timber (further details under "Planting key hosts" below; also see Table 5). Information about key natural enemies needs also to reach foresters and plant protection officials. Such outreach efforts to farmers and foresters could be modeled after efforts to promote integrated pest management programs (IPM) in Asia rice systems (Kenmore 1986).

\section{Replanting missing tree species in degraded-natural and other uncultivated areas}

To replant key tree species in degraded forests and elsewhere, local nurseries are needed that produce adequate numbers of seedlings of the desired species. Nursery propagation requires the local collection of viable seeds from well-preserved forests. For some species, reproduction by seed is difficult and vegetative reproduction procedures must be used. Tree species serving as fruit fly parasitoid reservoirs can be incorporated into the list of trees currently propagated by Mexican national and state funded tree nurseries and made available to farmers.

Management of parasitoid reservoirs by manipulating woody vegetation has been attempted in a few previous cases. In California, planting of French prunes in vineyards was used to locally enhance the numbers of Anagrus epos Girault, a key egg parasitoid of the grape leafhopper (Erythroneura elegantula Osborn) (Corbett and Rosenheim 1996; Murphy et al. 1998). In this case, the planted trees hosted another leafhopper (Dikrella californica [Lawson]) that the parasitoid required for an overwintering host. In another case, in-field production of the braconid parasitoid Ephedrus persicae Froggatt for control of rosy apple aphid (Dysaphis plantaginea [Passerini]) was achieved by planting rowan trees (Sorbus aucuparia) next to apple orchards. These acted as a host for the rowan aphid, Dysaphis sorbi Kaltenback, an alternate host of the parasitoid (Bribosia et al. 2005).

Proposals for similar vegetation manipulation programs to enhance fruit fly parasitoids in Mexico have been advanced (Ajua 1996, 1999; Aluja and Rull 2009). To enlarge the

Table 5 Economic uses of native trees that serve as parasitoid reservoirs and are recommended for replanting

\begin{tabular}{|c|c|c|c|}
\hline Tree species & Role & Fly host & Human value \\
\hline T. mexicana & Parasitoid multiplier & A. obliqua & Highly valuable timber/veneer (false mahogany) \\
\hline P. guajava & Pest-based reservoir & A. striata & Edible fruit \\
\hline$X$. americana & Reservoir & A. alveata & Substitute for sandalwood \\
\hline \multicolumn{4}{|c|}{ Species to conserve but not necessary to replant } \\
\hline M. floribunda & Reservoir & A. bahiensis & Hardwood for making kitchen tools \\
\hline Inga spp. & Reservoir & A. distincta & Shade tree for coffee and edible fruit \\
\hline
\end{tabular}


local pool of parasitoids available to attack A. obliqua, trees that are small-fruited alternate hosts of the pest (parasitoid multiplier species) or of related Anastrepha species (reservoir or pest-reservoir plants) should be planted adjacent to orchards, within orchards, or along rural roads (as shade trees or living fences), in parks and backyard gardens (for fruit), in coffee plantations (as shade trees), and in small-scale tree plantations (for high value timber production). We believe this approach would be very successful in rural areas of Latin America where local consumers tolerate higher levels of fruit damage compared with fruit destined for exportation to external markets.

\section{Legislative frameworks for preservation of biodiversity}

Due to its high species richness and endemism, tropical montane forests in Mexico are considered hotspots of biodiversity and one of the global conservation priorities (Myers et al. 2000). However, forest loss and degradation continues due in part to the lack of interest of landowners to preserve forest and appropriate laws to regulate land use. Previous removal of alternative hosts of fruit flies (many of them endemic and used as food sources by other animals) to control pests, did not take into account the other ecological and economic benefits that these species provide and are contrary to efforts to preserve forests or forest remnants (Dinerstein et al. 1995).

These multiple advantages derived from fruit fly host trees could provide authorities with additional reasons to strengthen conservation rules and regulations and help convince growers of the benefits that forest and other natural areas provide (Table 5).

Wood and other products Some tephritid-host plants could be grown in plantations or in a smaller scale for their valuable wood products. Species of Tapirira, for example, produce wood that compares in quality and appearance to that of mahogany (Terrazas and Wendt 1995 ) and is used as veneer and for making fine furniture. Furthermore its fruit are edible and its seeds are consumed as toasted nuts (Lascurain et al. 2010). The wood of $X$. americana, another key fruit fly host, is used as a substitute for sandalwood, its bark for tanning leather, its seeds as a natural purgitive, and its fruit are consumed fresh, boiled or in preserves (Lascurain et al. 2010). Spondias mombin wood is used to produce boxes, crates, and matches and some people use its leaves and bark as cleaning agent in eyes and wounds (Lascurain et al. 2010). Finally, wood from trees in the genus Chrysophyllum is used for tool handles, flooring, rural constructions, and general carpentry (Kribs 1968; Lascurain et al. 2010). The market value of such woods makes our proposed scheme of potential interest to farmers and agencies in charge of reforestation and habitat conservation. Trees that both enhance biological control of highly visible pests and produce valuable lumber would be ideal for reforestation programs.

Protection of rare fauna, charismatic and otherwise A further benefit from forest restoration and other forms of tree cultivation as a means of enhancing fruit fly biological control would be preservation of certain rare tephritids that otherwise face the danger of extinction. Conservation of insects is usually concerned with large, colorful species, principally butterflies and beetles (see Samways 2007), and appreciation of endangered Tephritidae is complicated by the better-known species being pests (Aluja and Norrbom 2000; Aluja and Mangan 2008). But, of over 5000 described tephritid species, fewer than $25(0.5 \%)$ have any pest status. 
Table 6 Threatened fruit fly species (Diptera: Tephritidae) in Veracruz, Mexico

\begin{tabular}{llll}
\hline Fly species & Host plant & Family & References \\
\hline Anastrepha alveata & Ximenia americana & Olacaceae & Piedra et al. (1993) \\
A. aphelocentema & Pouteria hypoglauca & Sapotaceae & Patiño (1989) \\
A. bahiensis & Myrciaria floribunda & Myrtaceae & Aluja et al. (2000) \\
A. bahiensis & Pseudolmedia oxyphyllaria & Moraceae & Hernández-Ortíz and \\
& & & Pérez-Alonso (1993) \\
A. bezzi & Unknown & & Hernández-Ortíz and \\
& & & Pérez-Alonso (1993) \\
A. crebra & Quararibea funebris & Bombacaceae & Hernández-Ortíz and \\
& & & Pérez-Alonso (1993) \\
A. dentata & Unknown & Aluja et al. (2000) \\
A. hamata & Chrysophyllum mexicanum & Sapotaceae & Lopez et al. (1999) \\
A. limae & Unknown & & Aluja et al. (2000) \\
A. robusta & Unknown & & Aluja et al. (2000) \\
Hexachaeta pardalis & Trophis mexicana & Aluja et al. (2000) \\
Rhagoletis turpiniae & Turpinia occidentales breviflora & Staphyleaceae & Hernández-Ortíz and \\
Rhagoletis turpiniae & T. insignis (H.B.\& K.) Tul & Pérez-Alonso (1993) & Hernández-Ortíz \\
& & & (1993)
\end{tabular}

Many species of fruit flies are severely threatened by the disappearance of native forests and severe habitat fragmentation (Aluja 1999; Aluja et al. 2003). For example, Anastrepha hamata (Loew) lives in close association with Chrysophyllum mexicanum Brandegee ex Standl. (Sapotaceae), its only known host plant (Aluja et al. 2000), which can still be found in tropical subdeciduous and decidious forests and in tropical evergreen rainforests in Veracruz, Mexico but is rare (see Table 6 for more examples of threatened species of Anastrepha, Hexachaeta, and Rhagoletis in Mexico). These environments have already been or are rapidly being replaced by rangeland or agroecosystems. Flies whose habitat is greatly reduced are likely to go extinct, locally and then globally, or suffer genetic degradation due to high degrees of interbreeding in small isolated populations surviving in fragmented forests (Valiente-Banuet and Verdú 2013). While not all the host trees of these flies would be targets for biological control-based replanting, preservation of remaining intact forest areas, through recognition by farmers of their timer and biological control value, would also protect trees that serve as hosts for these rare flies and other more appreciated fauna such as birds.

\section{Conclusions}

In summary, we argue that conservation of both insect and plant biodiversity will be promoted through the implementation of the vegetation restoration and management plans similar to that described here. Further, we believe that such plans could enjoy both farmer and government support because of pest control benefits to farmers and profits from farmer-production of native hardwoods. In countries such as Mexico, there is not sufficient 
land to view conservation and agriculture as totally separate activities that occur on separate parcels of land. The current high level of deforestation in tropical countries requires that agriculture and its needs be included in conservation planning (Vandermeer and Perfecto 2007) and be orchestrated by teams composed of farmers, social organizations, conservation groups, and governmental agencies dedicated to forestry conservation (Scherr and McNeely 2008). The fact that rural communities strongly depend on certain ecosystem services that cannot be provided by radically transformed landscapes creates the opportunity for farmers, once they understand the sources of these services, to create environments that better retain critical native biodiversity (Scherr and McNeely 2008). The vegetation management we propose is rooted in these concepts and has the potential to identify landscape components whose conservation can assist fruit production in tropical Mexico by providing pest reduction services likely to be lost in highly modified landscapes. Such out-of-field biological control services have been valued, for US farms at $\$ 4.5$ billion annually (Losey and Vaughan 2006) but currently are not appreciated in many tropical areas. For example, in Mexico the National Campaign to Combat Fruit Flies spends US \$521 to produce a million parasitoids for augmentative release (personal communication by J.M. Gutiérrez Ruelas, National Coordinator of Mexican Campaign for Fruit Flies). Considering that in one mango season, the number of parasitoids needed to reduce fly infestation is around 33,000 parasitoids/ha (Montoya et al. 2000), the cost of augmentative biological control in 1 ha of mango is US \$ 17.19 at current exchange rates. For un-capitalized growers in Latin America this cost is acceptable, but could be reduced if the use of parasitoid reservoir trees was implemented to produce thousands of parasitoids in situ. By increasing the value of forest and vegetation patches to farmers, the rate of loss of these areas due to agricultural conversion might be slowed. This program provides a path by which small landholders and orchard owners in Veracruz who control a substantial part of the land of the region can be steered toward more environmentally friendly pest control and sustainable forest management, reducing damage to wildlife and protecting farmers from health risks associated with pesticideintensive fruit production.

\section{Future research needs}

Our model identifies the tree species whose conservation is necessary and the timing of their fruiting, but additional work is needed to quantify the per tree output of flies and parasitoids from each tree type and the timing of their emergence. How many trees and of what types will be required, and how close they must be to orchards, are examples of questions for which answers must be determined experimentally to foster connectivity between parasitoid reservoirs and orchards. It will be necessary to determine how to provide parasitoids with enough stepping stones (patches of fruiting host trees) in time and space to manage pest fruit flies regionally on a year round basis and to quantify the ability of parasitoids to suppress fruit fly populations as they pass through population bottlenecks on particular types of wild fruit trees. Such efforts will require the development, through research, of new information on biology and ecology of the targeted tree and parasitoid species. With the acquisition of such information farmers, conservation agencies, and reforestation agencies will be able to make informed choices about the future of forest biodiversity and orchard pest control in Mexico and other regions where pestiferous tephritids and their natural enemies exploit native and commercial host plants. 
Acknowledgments We thank Maurilio López, Jaime Piñero, César Ruiz, Enrique Piedra and Isabel Jácome (formerly Instituto de Ecología AC, Xalapa, Veracruz, Mexico [INECOL]) for technical support and Griselda Benitez-Badillo and Ana Isabel Suárez-Guerrero for sharing information. We are particularly indebted to Daniel Piñero (Instituto de Ecología, UNAM, Mexico) for suggesting the title of this paper. Work reported here was in part supported by the following institutions: Comisión Nacional para el Conocimiento y Uso de la Biodiversidad (CONABIO-Mexico, Grant H-296), U.S. Department of Agriculture, Office of International Cooperation and Development (USDA-OICD, Project No. 198-23), Consejo Nacional de Ciencia y Tecnología-Sistema Regional Golfo de México (CONACyT-SIGOLFO, Proyecto 96-01003-V) and by the Campaña Nacional Contra las Moscas de la Fruta (Convenio SAGARPA-IICA). During the preparation of this manuscript the late AAD was a postdoctoral fellow of SAGARPA-IICA in INECOL and CONACyT at El Colegio de la Frontera Sur.

Open Access This article is distributed under the terms of the Creative Commons Attribution License which permits any use, distribution, and reproduction in any medium, provided the original author(s) and the source are credited.

\section{References}

Aluja M (1994) Bionomics and mananagment of Anastrepha. Annu Rev Entomol 39:155-178

Ajua M (1996) Future trends in fruit fly management. In: McPheron BA, Steck GJ (eds) Fruit fly pests: world assessment of their biology and management. St. Lucie Press, Delray Beach, pp 309-320

Aluja M (1999) Fruit fly (Diptera: Tephritidae) research in Latin America: Myths, realities and dreams. An Soc Entomol Brasil 28:565-594

Aluja M, Birke A (1993) Habitat use by Anastrepha obliqua flies (Diptera: Tephritidae) in a mixed mango and tropical plum orchard. Ann Entomol Soc Am 86:799-812

Aluja M, Mangan RL (2008) Fruit fly (Diptera: Tephritidae) host status determination: critical conceptual, methodological, and regulatory considerations. Annu Rev Entomol 53:473-502

Aluja M, Norrbom AL (2000) Fruit flies (Tephritidae): phylogeny and evolution of behavior. CRC Press, Boca Raton

Aluja M, Rull J (2009) Managing pestiferous fruit flies (Diptera: Tephritidae) through environmental manipulation. In: Aluja M, Leskey T, Vincent $\mathrm{C}$ (eds) Biorational tree fruit pest management. CAB International, Wallingford, pp 214-252

Aluja M, López M, Sivinski J (1998) Ecological evidence for diapause in four native and one exotic species of larval-pupal fruit fly (Diptera: Tephritidae) parasitoids in tropical environments. Ann Entomol Soc Am 91:821-833

Aluja M, Piñero J, López M, Ruíz C, Zúñiga A, Piedra E, Díaz-Fleischer F, Sivinski J (2000) New host plant and distribution records in Mexico for Anastrepha spp., Toxotrypana curvicauda Gerstacker, Rhagoletis zoqui Bush, Rhagoletis sp., and Hexachaeta sp. (Diptera: Tephritidae). Proc Entomol Soc Wash 102:802-815

Aluja M, Rull J, Sivinski J, Norrbom AL, Wharton RA, Macías-Ordóñez R, Díaz-Fleischer F, López M (2003) Fruit flies of the genus Anastrepha (Diptera: Tephritidae) and associated native parasitoids (Hymenoptera) in the tropical rainforest biosphere reserve of Montes Azules, Chiapas, Mexico. Environ Entomol 32:1377-1385

Aluja M, Montoya P, Cancino J, Guillén L, Ramírez-Romero R (2008) Moscas de la fruta, Anastrepha spp. (Diptera: Tephritidae). In: Arredondo-Bernal HC, Rodríguez-del-Bosque LA (eds) Casos de Control Biológico en México. México-España, Editorial Mundi-Prensa, pp 193-222

Aluja M, Ordano M, Teal PEA, Sivinski J, García-Medel D, Anzures-Dadda A (2009) Larval feeding substrate and species significantly influence the effect of a juvenile hormone analog on sexual development/performance in four tropical tephritid flies. J Insect Physiol 55:231-242

Antón C, Zeisset I, Musche M, Durka W, Boomsma JJ, Settele J (2007) Population structure of a large blue butterfly and its specialist parasitoid in a fragmented landscape. Mol Ecol 16:3828-3838

Band PR, Abanto Z, Bert J, Lang B, Fang R, Gallagher RP, Le ND (2011) Prostate cancer risk and exposure to pesticides in British Columbia Farmers. Prostate 71:168-183

Bergerot B, Julliard R, Baguette M (2010) Dynamics of metacommunities: decline of functional relationship along a habitat fragmentation gradient. PLoS One 5:e11294. doi:10.1371/journal.pone.0011294

Boller EF, Remund U, Candolfi MP (1988) Hedges as potential sources of Typholodromus pyri, the most important predatory mite in vineyards of northern Switzerland. Entomophaga 33:249-255 
Bomfim DA, Uchôa-Fernandes MA, Bragança MA (2007) Hosts and parasitoids of fruit flies (Diptera: Tephritoidea) in the State of Tocantins, Brazil. Neotrop Entomol 36:984-986

Bradshaw CA, Sodhi NS, Brook BW (2009) Tropical turmoil: a biodiversity tragedy in progress. Front Ecol Environ 7:79-87

Bribosia E, Bylemans D, Migon M, Van Impe G (2005) In-field production of parasitoids of Dysaphis plantaginea by using the rowan aphid, Dysaphis sorbi, as substitute host. Biocontrol 50:601-610

Canal NAD, Zucchi RA, da Silva NM, Leonel FL Jr (1994) Reconocimiento de las especies de parasitoides (Hy.: Braconidae) de moscas de las frutas (Dip.: Tephritidae) en dos municipios del Estado de Amazonas, Brasil. Boletín del Museo de Entomología de la Universidad del Valle 2:1-17

Canal NAD, Zucchi RA, da Silva NM, Silveira-Neto S (1995) Análise faunística dos parasitóides (Hymenoptera, Braconidae) de Anastrepha spp. (Diptera, Tephritidae) em Manaus e Iranduba, Estado do Amazonas. Acta Amazon 25:235-246

Castillo-Campos G, Halffter SG, Moreno CE (2008) Primary and secondary vegetation patches as contributors to floristic diversity in a tropical deciduous forest landscape. Biodiver Conserv 17:1701-1714

CONABIO (2008) Estrategia nacional sobre biodiversidad. http://www.conabio.gob.mx/conocimiento/ estrategia_nacional/doctos/estnacbio.html. Accessed 01 Jul 2010

Corbett A, Plant RE (1993) Role of movement in the response of natural enemies to agroecosystem diversification: a theoretical evaluation. Environ Entomol 22:519-531

Corbett A, Rosenheim JA (1996) Impact of a natural enemy overwintering refuge and its interaction with the surrounding landscape. Ecol Entomol 2:155-164

De Souza AR, Lopes-Mielezrski GN, Lopes EN, Querino RB, Corsato CDA, Giustolin TA, Zucchi RA (2012) Hymenopteran parasitoids associated with frugivorous larvae in a Brazilian Caatinga-Cerrado ecotone. Environ Entomol 4:233-237

Dinerstein E, Olson D, Graham D, Webster S, Primm S, Bookbinder M, Ledec G (1995) A conservation assessment of the terrestrial ecoregions of Latin America and the Caribbean. World Wildlife Fund and World Bank, Washington

Eskafi FM (1990) Parasitism of fruit flies Ceratits capitata and Anastrepha spp. (Diptera: Tephritidae) in Guatemala. Entomophaga 35:355-362

Favari L, Favari L, Lopez E, Martinez-Tabche L, Diaz-Pardo E (2002) Effect of insecticides on plankton and fish of Ignasio Ramirez reservoir (Mexico): a biochemical and biomagnification study. Ecotox Envion Safe 51:177-186

Fischer J, Lindenmayer DB (2007) Landscape modification and habitat fragmentation: a synthesis. Global Ecol Biogeogr 16:265-280

González-Astorga J, Castillo-Campos G (2004) Genetic variability of the narrow endemic tree Antirhea aromatica (Rubiaceae, Guettardeae) in a tropical forest of Mexico. Ann Botany 93:521-528

Harvey CA, Komar O, Chazdon R, Ferguson BG, Finegan B, Griffith DM, Martínez-Ramos M, Morales H, Nigh R, Soto-Pinto L, Van Breugel M, Wishnie M (2008) Integrating agricultural landscapes with biodiversity conservation in the Mesoamerican hotspot. Conserv Biol 22:8-15

Hernández AF, Parron T, Tsatsakis AM, Requena M, Alarcon R, López-Guarnido O (2013) Toxic effects of pesticide mixtures at a molecular level: their relevance to human health. Toxicology 307:136-145

Hernández-Ortíz V (1993) Description of a new Rhagoletis species from tropical Mexico (Diptera: Tephritidae). Proc Entomol Soc Wash 95:418-424

Hernández-Ortíz V, Aluja M (1993) Listado de especies del género neotropical Anastrepha (Diptera: Tephritidae) con notas sobre su distribución y plantas hospederas. Folia Entomol Mex 88:89-105

Hernández-Ortíz V, Pérez-Alonso R (1993) The natural host plants of Anastrepha (Diptera: Tephritidae) in a tropical rain forest of Mexico. Fla Entomol 76:447-460

Hernández-Ortiz V, Pérez-Alonso R, Wharton RA (1994) Native parasitoids associated with the genus Anastrepha (Dipt.: Tephritidae) in Los Tuxtlas, Veracruz. Mexico. Entomophaga 39:171-178

Hsu IC, Feng HT (2006) Development of resistance to Spinosad in oriental fruit fly (Diptera: Tephritidae) in laboratory selection and cross-resistance. J Econ Entomol 99:931-936

Kareiva P (1987) Habitat fragmentation and the stability of predator-prey interactions. Nature 326:388-390

Kenmore PE (1986) Some aspects of integrated pest management in rice. Plant Prot Bull 38:11-13

Kjeldsen LS, Ghisari M, Bonefeld-Jorgensen EC (2013) Currently used pesticides and their mixtures affect the function of sex hormone receptors and aromatase enzyme activity. Toxicol Appl Pharm 272:453-464

Klein AM, Steffan-Dewenter I, Tscharntke T (2006) Rain forest promotes trophic interactions and diversity of trap-nesting Hymenoptera in adjacent agroforestry. J Anim Ecol 75:315-323

Kribs DA (1968) Commercial foreign wood on the American market. Dover Publications Inc., New York

Kruess A, Tscharntke T (2000) Species richness and parasitism in a fragmented landscape: experiments and field studies with insects on Vicia sepium. Oecologia 122:129-137 
Lascurain M, Avendaño S, del Amo S, Niembro A (2010) Guía de Frutos Silvestres Comestibles en Veracruz. Fondo Sectorial para la Investigación, el Desarrollo y la Innovación Tecnológica Forestal, Conafor-Conacyt, Mexico

Lopez M, Aluja M, Sivinski J (1999) Hymenopterous larval-pupal and pupal parasitoids of Anastrepha flies (Diptera: Tephritidae) in Mexico. Biol Control 15:119-129

Losey JE, Vaughan M (2006) The economic value of ecological services provided by insects. Bioscience 56:311-323

Mangan RL, Moreno D (2007) Development of bait stations for fruit fly population suppression. J Econ Entomol 100:440-450

McQuate GT, Peck SL, Barr PG, Sylva CD (2005) Comparative evaluation of spinosad and phloxine B as toxicants in protein baits for suppression of three fruit fly (Diptera: Tephritidae) species. J Econ Entomol 98:1170-1178

Messing RH, Klungness LM, Purcell MF (1994) Short-range dispersal of mass-reared Diachasmimorpha longicaudata and D. tryoni (Hymenoptera: Braconidae), parasitoids of Tephritid fruit flies. J Econ Entomol 87:975-985

Messing RH, Purcell MF, Klungness LM (1995) Short range dispersal of mass-reared Psyttalia fletcheri (Hymenoptera: Braconidae), parasitoids of Bactrocera cucurbitae (Diptera: Tephritidae). Environ Entomol 24:1338-1343

Messing RH, Klungness LM, Jang EB (1997) Effects of wind on movement of Diachasmimorpha longicaudata, a parasitoid of tephritid fruit flies, in a laboratory flight tunnel. Entomol Exp Appl 82:147-152

Montoya P, Liedo P, Benrey B, Cancino J, Barrera JF, Sivinski J, Aluja M (2000) Biological control of Anastrepha spp. (Diptera: Tephritidae) in mango orchards through augmentative releases of Diachasmimorpha longicaudata (Ashmead) (Hymenoptera: Braconidae). Biol Control 18:216-224

Montoya P, Cancino J, Zenil M, Santiago G, Gutiérrez JM (2007) The augmentative biological control component in the Mexican national campaign against Anastrepha spp. fruit flies. In: Vreysen MJB, Robinson AS, Hencrichs J (eds) Area-wide control of insect pests: from research to field implementation. Springer, Dordrecht, pp 661-670

Moreno D, Mangan RL (2002) A bait matrix for novel toxicants for use in control of fruit flies (Diptera: Tephritidae). In: Hallmann G, Schwalbe CP (eds) Invasive arthropods in agriculture. Science, Enfield, pp 333-362

Mortelliti A, Amori G, Boitani M (2010) The role of habitat quality in fragmented landscapes: a conceptual overview and prospectus for future research. Oecologia 163:535-547

Murphy BC, Rosenheim RJ, Dowell AV, Granett J (1998) Habitat diversification tactic for improving biological control: parasitism of the western grape leafhopper. Entomol Exp Appl 87:225-235

Murray KE, Thomas SM, Bodour AA (2010) Prioritzing research for trace pollutants and emerging contaminants in the freshwater environment. Environ Pollut 158:3462-3471

Myers N, Mittermeier RA, Mittermeier G, da Fonseca AB, Kent J (2000) Biodiversity hotspot for conservation priorities. Nature 403:853-858

Newton A, Cayuela L, Echeverría C, Armesto J, Del Castillo RF, Golicher D, Geneletti D, González Espinosa M, Huth A, López Barrera F, Malizia L, Manson RH, Premoli AC, Ramírez Marcial N, Rey Benayas JM, Rüger N, Smith-Ramírez C, Williams Linera G (2009) Toward integrated analysis of human impacts on forest biodiversity: Lessons from Latin America. Ecol Soc 14:1-42

Ovruski S, Aluja M, Sivinski J, Warthon RA (2000) Hymenopteran parasitoids on fruit infesting Tephritidae (Diptera) in Latin America and Southern United States: diversity, distribution, taxonomic status and their use in fruit fly biological control. Integr Pest Manag Rev 5:81-107

Patiño J (1989) Determinación de las especies de Anastrepha Schiner (Diptera: Tephritidae) en frutales ycítricos de Papantla y Gutiérrez Zamora, Veracruz. Bsc. Thesis, Universidad Veracruzana, Tuxpan, Veracruz,Mexico.

Piedra E, Zuñiga A, Aluja M (1993) New host plant and parasitoid record in Mexico for Anastrepha alveata Stone (Diptera: Tephritidae). Proc Entomol Soc Wash 95:127

Raga A, Sato ME (2005) Effect of spinosad bait against Ceratitis capitata (Wied.) and Anastrepha fraterculus (Wied.) (Diptera: Tephritidae) in laboratory. Neotrop Entomol 34:815-832

Reyes J, Santiago G, Hernández P (2000) The Mexican fruit fly eradication programme. In: Tan KH (ed) Area-wide control of fruit flies and other insect pests. Penang, Penerbit Universiti Sains, Malaysia, pp 377-380

Rzedowski J (1996) Análisis preliminar de la flora vascular de los bosques mesófilos de montaña de México. Acta Bot Mex 35:25-44

Samways MJ (2007) Insect conservation: a synthetic management approach. Annu Rev Entomol 52:465-487

Scherr SJ, McNeely JA (2008) Biodiversity conservation and agricultural sustainability: towards a new paradigm of 'ecoagriculture' landscapes. Philos Trans R Soc B 363:477-494 
Sivinski J (1991) The influence of host fruit morphology on parasitization rates in the Caribbean fruit fly, Anastrepha suspensa. Entomophaga 36:447-454

Sivinski J, Aluja M (2012) The role of parasitoid foraging for hosts, food and mates in the augmentative biological control of Tephritidae. Insects 3:668-691

Sivinski JM, Calkins CO, Baranowski RM, Harris D, Brambila J, Díaz J, Bums RE, Holler T, Dodson D (1996) Supression of Caribbean fruit fly (Anastrepa suspensa (Loew) Diptera: Tephritidae) population through releases of the parasitoid Diachasmimorpha longicaudata (Ashmead) (Hymenoptera: Braconidae). Biol Control 6:177-185

Sivinski J, Piñero J, Aluja M (2000) The distributions of parasitoids (Hymenoptera) of Anastrepha fruit flies (Diptera: Tephritidae) along an altitudinal gradient in Veracruz, Mexico. Biol Control 18:258-269

Sivinski J, Vulinec K, Aluja M (2001) Ovipositor length in a guild of parasitoids (Hymenoptera: Braconidae) attacking Anastrepha spp. fruit flies (Diptera: Tephritidae) in southern Mexico. Ann Entomol Soc Am 94:886-895

Smith D, Papacek DF (1991) Studies of the predatory mite Amblyseius victoriensis (Acarina: Phytoseiidae) in citrus orchards in south-east Queensland: control of Tegolophus australis and Phyllocoptruta oleivora (Acarina: Eriophyidae), effect of pesticides, alternative host plants, and augmentative release. Exp Appl Acarol 12:195-217

Stark JD, Vargas R, Miller N (2004) Toxicity of spinosad in protein bait to three economically important tephritid fruit fly species (Diptera: Tephritidae) and their parasitoids (Hymenoptera: Braconidae). J Econ Entomol 97:911-915

Tanksley SD (2004) The genetic, developmental, and molecular bases of fruit size and shape variation in tomato. Plant Cell 16:S181-S189

Terrazas T, Wendt T (1995) Systematic wood anatomy of the genus Tapirira Aublet (Anacardiaceae)—a numerical approach. Brittonia 47:109-129

Thies C, Roschewitz I, Tscharntke T (2005) The landscape context of ceral aphid-parasitoid interactions. Proc R Soc B 272:203-210

Thompson JN (1996) Evolutionary ecology and the conservation of biodiversity. Trends Ecol Evol $11: 300-303$

Tscharntke T, Bommarco R, Clough Y, Crist TO, Kleijn D, Rand TA, Tylianakis JM, Nouhuys SV, Vidal S (2007) Conservation biological control and enemy diversity on a landscape scale. Biol Control 43:294-309

Uchôa-Fernandes M, da S Molina RM, Oliveira I, Zucchi RA, Canal NA, Díaz NB (2003) Larval endoparasitoids (Hymenoptera) of frugivorous flies (Diptera, Tephritoidea) reared from fruits of the cerrado of the State of Mato Grosso do Sul, Brazil. Rev Bras Entomol 47:181-186

Valiente-Banuet A, Verdú M (2013) Human impacts on multiple ecological networks act synesgistically to drive ecosysem collapse. Front Ecol Environ. doi:10.10/130002

Van Nouhuys S, Hanski I (2002) Colonization rates and distances of a host butterfly and two specific parasitoids in a fragmented landscape. J Anim Ecol 71:639-650

Vandermeer J, Perfecto I (2007) The agricultural matrix and a future paradigm for conservation. Conserv Biol 21:274-277

Velázquez A, Mas JF, Díaz-Gallegos JR, Mayorga-Saucedo R, Alcántara PC, Castro R, Fernández T, Bocco G, Ezcurra E, Palacio JL (2002) Patrones y Tasas de Cambio de Uso del Suelo en México. Gaceta Ecológica 62:21-37

Wang XG, Jarjees EA, McGraw BK, Bokonon-Ganta AH, Messing RH, Johnson MW (2005) Effects of spinosad-based fruit fly bait GF-120 on tephritid fruit fly and aphid parasitoids. Biol Control 365:155-162 